\title{
Why do Foreign Banks Withdraw from other Countries? A Panel Data Analysis
}

\author{
Aneta Hryckiewicz \\ Oskar Kowalewski
}

\author{
CESIFO WORKING PAPER NO. 3006 \\ CATEGORY 12: EMPIRICAL AND THEORETICAL METHODS \\ MARCH 2010
}
An electronic version of the paper may be downloaded
- from the SSRN website:
- from the RePEc website:
www.SSRN.com
Www.RePEc.org
- from the CESifo website:
www.CESifo-group.org/wp




\title{
Why do Foreign Banks Withdraw from other Countries? A Panel Data Analysis
}

\begin{abstract}
This paper describes the trends in foreign bank ownership across the world and presents, for the first time, empirical evidence of the causes of multinational banks' exits from other countries. Using panel data for 149 closed or divested foreign bank subsidiaries across 54 countries from 1997 to 2009, we show that the problems encountered by subsidiaries were not the main cause of divestment by parent banks. Based on data for the parent banks of the closed subsidiaries, our results show that those parent banks reported significant financial weaknesses prior to closing their international operations. Therefore, we assume that a multinational bank's decision to close or sell a subsidiary in another country is based mainly on problems in the home country, with a lesser factor being the weak performance of the foreign subsidiary.
\end{abstract}

JEL-Code: G21, G34, F20.

Keywords: foreign banks, subsidiary, divestment, performance.

Aneta Hryckiewicz

Chair of International Banking and Finance

Johann Wolfgang Goethe University

P.O. Box 111932

(Uni-Pf. 66)

Germany - 60054 Frankfurt am Main

hryckiewicz@finance.uni-frankfurt.de
Oskar Kowalewski

World Economy Research Institute

Warsaw School of Economics (SGH)

Al. Niepodleglosci 162

Poland-02-554 Warsaw

okowale@sgh.waw.pl

We would like to thank Giuliano Iannotta, Adrian Tschoegl, Michael Ermann, Reinhard Schmidt, Felix Noth, Todd Gormley and John Bonin for their very helpful comments. This paper has also benefited from comments made by the participants at the Ifo/CESifo \& ACES Conference on Banking and the Institutions, CICM Conference at the London Metropolitan Business School, the Goethe University and the Wharton School Brown Bag Seminar. The authors are grateful to CAREFIN and CESifo for the financial support of their research. 


\section{Introduction}

In the last few decades, empirical and theoretical banking research has concentrated on foreign bank entry and cross-border mergers and acquisitions ${ }^{1}$. While the spotlight has been focused principally on foreign entry, divestiture has quietly become an important phenomenon in the banking industry. In fact, the recent financial crisis and the prominence of divestiture are probably the most visible signs of the massive reallocation of multinational banks' assets across the countries in which they do business.

The divestment of foreign assets contrasts with the foreign entry strategy that many multinational banks pursued in the last two decades. As a result of this expansion, we have witnessed a surge in foreign bank assets across many countries in the world. Increased foreign ownership is particularly striking in emerging markets, especially in Latin America and Central and Eastern Europe, where foreign banks account for $50 \%$ or more of the total banking assets in a number of countries (Claessens et al., 2008). Hence, the following questions arise: Why do multinational banks divest their foreign operations at some point? Is divestment related to the situation of the foreign bank subsidiary or problems in the host country? Is the divestment of foreign assets instead a result of financial weakness of the parent bank, which may have been caused by a financial crisis in the home country?

In the existing literature on multinational banking, no empirical studies exist regarding the factors that might lead to the closure or sale of a foreign bank subsidiary. In this paper, using a unique database of 149 foreign banks' withdrawals from 54 countries in the period of 1997 2009, we aim to fill this gap in the literature and establish the possible determinants behind a parent bank's decision to close a foreign operation.

In our opinion, there are two main hypothesis reasons for a parent bank's decision to divest a foreign bank subsidiary. The first reason is the low profitability or financial distress of the foreign bank subsidiary in the host country. The second reason is the parent bank's financial problems in its home country, which may force it to close a foreign subsidiary to improve profitability and/or increase its own capital. The two hypotheses are not mutually exclusive. Hence, we also assume that the reason for closing a foreign operation may include simultaneous financial weakness of the subsidiary and the parent bank. Therefore, both hypotheses can be true under some circumstances; however, we try to establish which hypothesis has greater weight under the given conditions.

\footnotetext{
${ }^{1}$ Bhattacharya (1993) provides a comprehensive literature survey on foreign bank entry in developing countries, as do Berger, DeYoung, Genay and Udell (2000) on international cross-border banking performance.
} 
Using the financial statements of each subsidiary and its parent bank, we employed a random effects probit model to establish which hypothesis best explains the decision to close foreign subsidiaries in recent years. Our results show that the divestment decision results from the low profitability of both the parent bank and its foreign subsidiary. However, our analysis shows that greater weight should be placed on the parent bank's financial weakness than on the financial weakness of the subsidiary. Based on these findings, we believe that foreign exit decisions may illustrate the ongoing reorganisation of parent banks' operations to increase their profitability and/or capital, wherein less profitable and riskier assets are divested.

Our results are reinforced by the fact that we find no evidence of the influence of other factors on the parent banks' exit decisions. Nevertheless, we document that the likelihood of divestment increases during a financial crisis in both the home and host countries. In the past, similar explanations for the decline of foreign banks' shares abroad were presented by Tschoegl (2005) and Peek and Rosengren (2000). However, the work of Tschoegl (2005) was based mainly on case studies, and he failed to provide empirical evidence for his assumptions. Peek and Rosengren's (2000) research focused mainly on the effects of the Japanese financial crisis in the 1990s on foreign bank lending in the US.

Finally, the results of our sensitivity analysis, in which we separated developed and emerging markets, confirmed (but differed slightly from) our previous findings. Our results indicate that the closure of subsidiaries in developed countries may be associated mainly with a decline in the financial performance of the parent bank in the home country rather than with problems of the foreign subsidiary. However, in the case of developing countries, the weak performance of the subsidiary was an additional factor that contributed to the parent's divestment decision. In our opinion, our results confirm the different attitudes of foreign banks towards operations in developed and developing countries, which have been documented previously (Claessens et al., 2009).

We ensured that our findings were robust by subjecting them to additional tests. We used alternative econometric methods, changed the specifications of the dependent and exogenous variables, and altered our sample data. The main results of our study remain unaffected throughout these robustness checks.

The remainder of the paper is organised as follows. Section 2 reviews the relevant literature on exit decisions of foreign banks in general and presents our main hypotheses. Section 3 describes the sample data regarding foreign subsidiaries and parent banks. Section 4 presents the variables and the model employed in our analysis. Sections 5 and 6 discuss the empirical results. Section 7 concludes the discussion. 


\section{Theoretical predictions regarding the motivation for foreign bank subsidiary divestment}

In the last two decades, many countries, particularly those with emerging economies, have witnessed an increase in the activities of foreign banks in their banking sectors. In developing countries, this increase in activity has largely been led by the privatisation of state-owned banks and the rescue of distressed domestic financial institutions. Micco, Panizza, and Yañez (2004) reported that the average level of foreign bank participation among developing countries rose from $18 \%$ to $33 \%$ of total banking assets between 1995 and 2002. Today, in approximately $40 \%$ of all developing countries, more than $50 \%$ of banks have foreign owners. Strikingly, this figure exceeds $80 \%$ in several Central and Eastern European countries (Claessens et al., 2008).

We assume that multinational banks initially enter foreign markets to increase their profitability within an acceptable risk profile. Indeed, host and country characteristics related to profitability and risks have been found to be important drivers of banks' decisions to penetrate a foreign market. Focarelli and Pozzolo (2005), for example, found that banks prefer to maintain subsidiaries in countries where expected profits are larger because of higher expected economic growth and the prospect of benefiting from local banks' inefficiencies. De Haas and van Lelyveld (2010) found that parent banks support subsidiaries that report high net interest margins or low loan loss provisioning and, therefore, grow faster than the foreign subsidiaries of other multinational banks.

The entrance of foreign banks enhances the efficiency and improves the functioning of domestic banks. For instance, Claessens et al. (2001), using a dataset on domestic banks in 80 countries for the period of 1988-1995, showed that the increased presence of foreign banks is associated with reductions in the profitability, non-interest income and overall expenses of domestic banks. Apparently, the competitive pressure of foreign banks leads to positive efficiency effects in the banking sector of the host country. Moreover, these effects occur as soon as foreign banks enter the market and do not seem to depend on the market share of the foreign banks.

The results of Claessens et al. (2001) are supported by a number of country-specific empirical studies. For example, Denizer (1999) showed that in Turkey, the net interest rate margins, returns on assets and overhead expenses of domestic banks decreased after the entry of foreign banks. These changes in the banking sector occurred despite the fact that foreign banks possessed a market share of only $3.5-5.0 \%$ during the period of 1970-1997, which also 
confirmed that foreign bank entry alone increases competitive pressure in host banking markets.

While most studies have underlined the positive impact of foreign banks on increased banking competition in host countries, there have also been recent studies illustrating the negative effects of foreign entry. Giannetti and Ongena (2007) suggested that domestic banks might cut back their own lending in response to foreign entry. Likewise, Gormley (2010) found that firms were eight percentage points less likely to receive a loan after foreign bank entry because of a systematic drop in domestic bank loans.

As the host market evolves in response to foreign entry, local market opportunities and the comparative advantage of the foreign bank subsidiary may decline. This decline can result in lowered profitability of a foreign bank subsidiary, which may motivate the parent bank to close or sell it. Indeed, there have been several studies documenting the weak performance of foreign bank subsidiaries. For example, DeYoung and Nolle (1996) found that foreign-owned banks in the US performed significantly worse than domestic banks. In addition, recent experience has shown that declining profits were one of the reasons why some foreign banks decided to close their operations in host countries. For example, in 2003, the Spanish Banco Bilbao Vizcaya Argentaria (BBVA) sold its Brazilian operations to Bradesco after realising that it would be too expensive to achieve the asset size necessary to be profitable (Tschoegl, 2005). Therefore, our first hypothesis is the following:

Hypothesis 1: Parent banks close or sell their foreign subsidiaries due to the low profitability and/or financial distress of their foreign operations.

However, parent banks may decide to divest their foreign subsidiaries due to their own financial problems. Williams (1996) examined the performance of Japanese banks following Australia's removal of its entry restrictions and found that their market share peaked approximately eight years after entry. However, he later observed that the market share of those banks declined concurrently with the domestic problems of Japanese banks in the 1990s. Similar results were presented by Tschoegl (2004) for the US banking sector. He demonstrated that the assets of Japanese bank subsidiaries peaked in the early 1990s in California and then began to fall. Furthermore, Peek and Rosengren (2000), who investigated how the financial crisis in Japan in the early 1990s affected lending by Japanese banks in the US, showed that the position of Japanese banks in the US banking sector declined after the financial crisis.

The history of Japanese banks in the US and Australia shows that those parent banks that sold their subsidiaries did so as a result of problems in their home countries, not because of 
financial difficulties with their foreign operations. In addition, according to Tschoegl (2004), the Japanese banks sold their foreign operations to reduce costs and raise capital as the problems in their home country intensified due to the collapses of the stock market and land price bubble.

The closure or sale of foreign subsidiaries can also be a result of the collapse of the parent bank. For example, when Banco Ambrosiano, an Italian bank, collapsed in 1982, the Italian authorities protected Italian depositors by transferring the bank's business to a new Italian entity. However, they disclaimed responsibility for the obligations of Ambrosiano's Luxembourgian and Latin American subsidiaries. By contrast, when Demirbank failed in Turkey in 2000, its subsidiaries in Bulgaria and Romania continued to function, and there was no run on the banks in the host markets. Instead, those subsidiaries simply became an asset that the Turkish authorities sold separately while they liquidated the failed parent bank (Tschoegl, 2005). A similar situation occurred during the recent financial crisis, when the healthy international assets of Lehman Brothers were sold disposed after the US-based parent bank went bankrupt. Thus, based on the existing empirical evidence regarding multinational banks' behaviours, we propose our second hypothesis:

Hypothesis 2: Foreign bank subsidiaries are closed or sold as a result of the low profitability and/or financial problems of the parent bank in the home country.

These two hypotheses are not mutually exclusive. We assume that it is possible that the reason for divestment may be the simultaneous financial weakness of parent bank and the subsidiary. Consequently, we put forward our last hypothesis:

Hypothesis 3: Foreign banks' exits are motivated by the simultaneous low profitability and/or financial distress of the subsidiary and its parent bank.

\section{Data description}

The data on foreign bank withdrawal were hand-collected using Bureau van Dijk's BankScope and Zypher databases and various public resources, such as annual reports and newspapers. In our study, we define a withdrawal from a host country as a parent bank closing or selling its subsidiary to a domestic or foreign investor. We consider the term "foreign bank subsidiary" to mean locally incorporated banks with over $50 \%$ foreign ownership. 
Based on these criteria, we identified 149 foreign bank divestments in 39 different countries during the period of 1997-2009. Our sample included commercial and savings banks but excluded state banks and agencies of foreign banking organisations.

In our sample, most foreign bank subsidiaries were liquidated by their parent banks through sales to domestic or foreign investors. In a few cases, the government took control of the parent bank or its subsidiary as a consequence of financial distress. In the empirical analysis, we controlled for government intervention on the subsidiary or parent bank level using a dummy variable called Government. The variable takes a value of 1 if the bank has been taken over by any kind of government entity and 0 otherwise.

For all parent banks and subsidiaries, we obtained unconsolidated financial statements from the BankScope database for the year prior to the withdrawal, $t-1$. Using the financial statements, our sample period was 1987-2009, but the panel was unbalanced, as we do not have financial information for all years for each bank in our sample. Because not all banks report in the same currency, we converted the balance-sheet and income-statement variables of the parent banks and subsidiaries into US dollars.

Table 1 lists the identified divestments of foreign bank subsidiaries in host countries. The table illustrates that the greatest number of subsidiary closures took place in Latin America and Central and Eastern Europe. This finding is not surprising, as those regions have also reported the greatest number of foreign bank operations in the last two decades (Cerutti et al., 2007).

\section{[Table 1]}

Argentina and Indonesia experienced the largest number of foreign bank subsidiary closures. From 1997 to 2009, nine foreign bank subsidiaries were closed in Argentina, seven in Indonesia and five in Romania. Approximately half of the closures in Latin America and Asia in the sample period occurred from 2001 to 2003. The large number of closures in this period may have been associated with the financial crises in emerging markets that started in Asia in 1997, expanded in the following year into Russia and further expanded two years later into Brazil. Shortly thereafter, the financial crisis enveloped the Latin American continent. Simultaneously, in 2001, most industrialised countries went into a mild recession caused by the crash of the Internet bubble and the bankruptcy of Internet and technology companies around the world. As a consequence, the profitability of parent banks shrank - an event that may have prompted the divestment of subsidiaries in countries that were perceived as risky.

Peek and Rosengren (2000) and Tschoegl (2004) showed that a financial crisis in a home country might result in the scaling down of foreign operations by parent banks. However, 
studies on the behaviour of foreign banks during financial crises in host countries have provided mixed evidence. On one hand, Tschoegl (2005) argued that parent banks might sell their subsidiaries when host country markets are depressed and the risk to a parent bank of staying abroad is too high. Hence, foreign banks might depart quickly from any host market that faces political, economic or financial crises, as was the case in Asia in 1997 and Latin America in 1999. This departure occurs because crises often result in the erosion of the host country's economic potential, frequently causing foreign banks to suffer during a general downturn. Specifically, Crystal et al. (2001) and Dages et al. (2000) provided examples of the behaviours of parent banks during the Argentinian crisis. They showed that the closures of the French Crédit Agricole and the Canadian Scotiabank in Argentina were mainly motivated by the weak financial situations of their subsidiaries as a result of the crisis. In both cases, the parent banks were unwilling to recapitalise failed subsidiaries and decided to withdraw their operations, turning their subsidiaries over to the Argentinian government for rescue.

On the other hand, some academic studies have suggested that foreign banks tend to be less heavily impacted by crises than domestic banks, in part because they are often more conservative in their lending (Crystal et al., 2001). For example, Dages et al. (2000) showed that foreign banks in Argentina and Mexico exhibited stronger and less volatile loan growth over the period of 1994-1999 than did domestic banks. Other studies claimed that foreign banks could use economic crises and distortions in the banking industry to increase their market share in the existing market or to enter a new one. Indeed, Peek and Rosengren (2000) found evidence that foreign banks expanded in several Latin American countries as a result of liberalisations and worsening conditions in domestic markets. Consistent with this result, Guille and Tschoegl (2000) found that Spanish banks have increased their ownership in Argentina's banks during the economic crisis of the last decade. Additionally, Engwall et al. (2001) found that foreign banks started to increase their market share in Norway during the Scandinavian banking crisis in the early 1990s while, at the same time, reducing their presence in Sweden.

In the regression, we took into account the possible impact of crisis on parent banks' divestment decisions by including a dummy variable. The dummies Host Crisis and Home Crisis took on values of 1 for years in which the host country or home country, respectively, experienced a banking crisis. In addition, when we tested the third hypothesis, we used interaction dummies of home and host crises. The crisis dummy is based on Laeven and Valencia (2008); for 2008 and 2009, we constructed it based on Internet publications of the World Bank and the IMF. 
Table 2 shows the number of identified parent banks that decided to divest foreign subsidiaries from 1997 to 2009. However, we presented each parent bank only once per year regardless of the number of subsidiaries that were sold or closed in a given year. For example, in the table, the Dutch ABN Amro is shown only three times between 2000 and 2002, even though the number of subsidiaries closed by the bank was substantially greater than three. During this period, the bank's strategy was to allocate its resources to those markets that generated the highest possible profits for its clients and shareholders and to exit those markets that failed to fit that framework. As a result, ABN Amro sold all of its foreign operations in Aruba, Bahrain, Bolivia, Ecuador, Kenya, Morocco, Lebanon, Panama, Sri Lanka and Suriname in the period from 2000 to 2002. In addition, its retail operations in Argentina, Chile, the Philippines and Venezuela, its onshore banking activities in the Netherlands Antilles, and the retail and brokerage business in Greece were sold. However, for the purpose of the table, we counted ABN Amro only once per year because we were interested only in registering each parent bank that was divesting its foreign operations, not in the number of closed subsidiaries.

We also listed the parent bank even if the closure of a subsidiary was actually implemented by another foreign subsidiary that was owned by the parent bank. Since 2001, the Italian Banca Intesa closed several of its operations in North and South America. These foreign operations were controlled by Banque Sudameris, a subsidiary of Banca Intesa located in France. However, we counted the sale of Banque Sudameris' operations abroad as divestments of Banca Intesa.

The table illustrates that over this period, the greatest number of parent banks that divested a foreign subsidiary were from Western European countries. From 1997 to 2009, there were 19 disposal decisions made by Italian parent banks, 14 each by British and German parent banks, and 13 each by Dutch, French and US parent banks. However, these numbers do not reflect the scale and number of parent banks' foreign assets divestments in each of these countries, as explained above.

[Table 2]

\section{Empirical methodology}

We estimated three types of regressions to test our predictions from Section 2. In all regressions, the dependent variable, $D_{i, t}$, is a binary variable equal to 1 if parent bank $i$ from the home country $j$ closed or sold a foreign subsidiary in the host country $k$ in year $t$ and 0 if the parent bank still operates in the country. 
In the first regression, we only used the financial characteristics of the foreign bank subsidiary to test the first hypothesis:

$$
D_{i, t}=\alpha_{1}+\beta_{1} \text { Sub }_{i, t-1}+\beta_{2} \text { Host Country }_{k, t-1}+\epsilon_{i, k, t}
$$

where $S u b_{i, t}$ is a matrix of characteristics related to the divested foreign subsidiary $i$ by the parent bank $j$, and Host Country C $_{k}$ is a matrix of host country control variables.

In the second regression, we employed the financial characteristics of the parent bank and tested the second hypothesis:

$$
D_{i, t}=\alpha_{2}+\beta_{3} \text { Parent }_{i, t-1}+\beta_{4} \text { Home Country }_{l, t-1}+\epsilon_{i, j, t}
$$

where Parent $t_{i, t}$ is a matrix of characteristics related to the parent bank $I$, and Home Country is a matrix of home country control variables.

As these two hypotheses are not mutually exclusive, in the third regression, we used the financial characteristics of both the parent bank and its foreign subsidiary:

$$
\begin{aligned}
& D_{i, t}=\alpha_{1}+\beta_{1} \text { Sub }_{i, t-1}+\beta_{2} \text { Host Country }_{k, t-1}+\beta_{3} \text { Parent }_{j, t-1}+ \\
& +\beta_{4} \text { Home Country }_{l, t-1}+\beta_{5} \text { Host }- \text { Home Factors }_{k l, t-1}+\epsilon_{i, j, t}
\end{aligned}
$$

where Host-Home Factors $k, l, t$ is a matrix of variables that controls for the characteristics of both the home and host countries.

Because a multinational bank typically influences the participation of a foreign bank in a host market, the failure to simultaneously include multinational determinants alongside host country factors will result in a failure to adequately explain all aspects of a foreign bank's profitability (Williams, 2003). We were able to overcome this shortcoming by using an integrated model that combines both sets of factors to examine the determinants of foreign banks' profits. Moreover, the results of the model may not only indicate the reason for foreign closures but also explain the performance of foreign bank subsidiaries.

In all of the regressions, we employed the same bank-specific variables for the parent bank and its divested subsidiary. The key variable of interest, Profitability, was measured using return on average assets, which is calculated as net profit divided by average total assets. This measure does not control for the impact of any transfer pricing, but this cannot be assessed. We assume that bank profitability will be negatively related to the parent banks' divestment decisions regarding foreign assets.

Furthermore, we controlled, among other bank financial characteristics, for capital strength, loan activity, asset quality and liquidity. These variables may also signal the bank's financial problems, which may lead to the decision to exit the host market.

In our study, capital strength was represented by the equity to assets ratio (Equity), which measures the amount of protection offered to the bank by its equity. Wheelock and Wilson 
(2000) suggested that a bank's probability of disappearing is greater when its capitalisation is lower. They argued that this is true both in the acquisition of failing banks prior to insolvency and the purchase of banks by skilful managers who are able to operate successfully with high leverage. We therefore expect the ratio to be negatively related to the decision to close the foreign bank subsidiary.

We assume that banks enter new markets with the expectation of profits. To earn these profits, capital must be diverted from the parent bank's domestic activities. The application of capital would be anticipated to result in increased assets and loan sizes, while its reduction would be expected to harm the foreign bank's performance. We use Loans, calculated as net loans divided by total assets, to control for bank activity. An increase in loan activity in a parent bank's home market may result in a decrease in loan activity and profitability in the host markets. We may also expect that more resources will be devoted to the domestic market when a subsidiary reports lower profitability or when the parent bank encounters financial problems. As a result, we assume that loan activity will be negatively related to profitability and therefore also to foreign bank closure.

Bank weakness and divestment can be attributed to poor management, as manifested in excessive credit and worsening loan quality. As a measure of loan quality in our study, we used the ratio of loan loss provision to net interest revenue (Assets Quality). Peek and Rosengren (2000) illustrated that a parent bank's non-performing loans have an even more significant impact on operations in a host country than does a bank's capitalisation. An increase in this ratio represents poor loan quality, which should increase the odds of divestment.

Another important aspect that can influence the likelihood of subsidiary closure is a bank's liquidity position. We assume that banks that are particularly illiquid may find it difficult to avoid closure because they have encountered liquidity problems that are difficult to overcome. In our study, we considered the ratio of liquid assets to the number of customers and amount of short-term funding (Liquidity). Higher liquidity, profitability and equity values are expected to indicate lower bank riskiness.

Table 3 lists the independent variables and their mean values for the parent bank and its subsidiary for one year prior to the subsidiary's closure. The mean values of the independent variables for the parent banks are significantly different from the values of their subsidiaries in two cases. First, the mean profitability shows a statistically significant difference between parent banks and their foreign subsidiaries. Thus, our results suggest that the closed foreign subsidiaries are, on average, less profitable than their parent banks. As foreign subsidiaries 
have similar proportions of loans and non-performing assets to those of the parent bank, the subsidiary's lower profitability may be attributed to either lower net interest margins or higher overall costs.

Second, foreign subsidiaries have statistically significantly lower levels of liquidity than their parent banks. Hence, the difference of means test revealed that foreign subsidiaries are, on average, not only less profitable but also riskier than their parent banks. Our findings appear to be consistent with Leveen and Praveen (1994), who compared the performance of foreign-owned versus domestic US banks. They also reported that foreign banks operate with greater risk exposures than their domestically owned counterparts. In addition, they show that foreign banks are significantly less profitable than domestic institutions.

As a result, the univariate statistics may, to a certain extent, confirm the initial assumptions that the closure of a foreign subsidiary is caused by its low profitability rather than by the parent bank's problems in the home country. On the other hand, the standard deviation of the profitability variable for the parent banks shows that the second and third hypotheses cannot be ruled out at this point. In particular, parent banks, on average, report lower levels of equity and higher costs of nonperforming loans than do their foreign subsidiaries, which can signal financial difficulties in the home market.

[Table 3]

In the regressions, we used additional explanatory variables to control for differences between the home and host countries. First, we used a dummy that takes a value of 1 if the subsidiary is located in a less developed country $(L D C)$ and 0 otherwise. Several studies have found that a country's level of development may influence foreign bank performance compared to domestic banks (Claessens et al., 2009).

Second, we included a dummy to control for the geographical distance between the parent bank and the subsidiary. The Distance dummy takes the value of 1 if the subsidiary and the parent bank are from the same region and 0 otherwise. We assume that the distance between the host and home countries has a negative impact on performance, as it may increase the cost of management or reduce efficiency in other ways. Berger and DeYoung (2006), for example, found that distance determines the effectiveness of internal control mechanisms within bank holding companies.

Finally, we included region dummies for Asia and Australia, Europe and Latin America. These dummy variables control for additional regional disparities that may motivate foreign bank exits and cause an omitted variable bias. 
We employed the random panel probit to estimate Eqs. (1-3). We assumed that all unobservable factors that influence individual bank behaviours but are not captured by our regressors could be summarised by a random error term. Another option would have been to estimate the bank-specific effects as fixed parameters. Because our panel contains many banks relative to years, this would imply that many degrees of freedom would be lost. However, we used the panel logit model with fixed effects in the robust regression. Thus, our results are weaker because we lose a large quantity of information, but the main coefficients do not change their signs.

\section{Empirical results}

In this section, we report the results for the panel probit estimation of Eqs. (1-3). For each regression, we present six alternative specifications, adding different proxies for bank and country characteristics. All regressions were estimated with robust standard errors, allowing for the possibility that observations for the same parent bank may not be independent.

The estimated coefficients themselves do not indicate a change in the probability of the event occurring given a one-unit change in the relevant explanatory variable. The sign of the estimated coefficient only indicates the direction of the change in probability. The size of the change in probability will differ based on the initial values of all explanatory variables and their coefficients. Thus, it is conventional to evaluate the explanatory variables relative to their mean values as a basis for inferring a change in probability. Consequently, in Tables 4-6, the last column presents the elasticity at means, which indicates the percentage change in the probability of closing a foreign bank subsidiary as a result of a one-percent change in the relevant explanatory variable when all variables are evaluated around their mean values.

\subsection{Main results}

Table 4 presents the estimated model using data for the closed foreign bank subsidiaries only. The results show that low subsidiary profitability may be the main reason for its divestment by the parent bank, which would be in line with our first hypothesis. The profitability coefficient is negative and highly significant in each specification. The addition of control variables does not significantly change the profitability coefficient. Furthermore, the elasticity at means confirms that profitability is the main factor, and its value implies that a decrease in return on assets of $1 \%$ increases the likelihood of divestment by $1.67 \%$. 
The coefficient of loan loss provision is positive and statistically significant, meaning that the subsidiary's asset quality has improved prior to the divestment. Furthermore, the loan activity ratio shows a non-significant increase. As a consequence, we assume that one of the reasons for divestment may be low interest margins or high overhead costs, which could explain the subsidiary's low profitability.

The dummy variable representing government intervention is positive and significant. We do not, however, find evidence that a financial crisis in the host country increases the likelihood of closing the foreign subsidiary. The dummy crisis coefficient is positive but not statistically significant. Finally, almost all of the remaining coefficients have the expected signs, but they are not statistically significant.

[Table 4]

Table 5 gives the results of estimating Eq. (2). The results show that one year prior to subsidiary closure, the coefficient of the parent bank's profitability is negative but statistically insignificant. In the regression, only the home crisis dummy turns out to be positive and significant. Our results therefore show that the likelihood of divestment of a foreign operation increases in cases of financial crises in home markets.

The remaining variables do not provide any further evidence of financial weakness of the parent bank. The declines in equity and loan activity may signal some financial distress, but their coefficients are insignificant. By contrast, the variables for liquidity and loan quality show a positive situation of the parent bank. Nevertheless, the variables are also statistically insignificant. As a consequence, we do not find support for the second hypothesis.

\section{[Table 5]}

Finally, Table 6 shows the results for the regression model (3), in which we test if the divestment decision was caused by the simultaneous low profitability of the subsidiary and the parent bank. In all of the regressions, the profitability coefficient for the parent banks and their subsidiaries were negative and statistically significant. In all of the specifications, it remained negative and highly significant after the inclusion of the additional control variables.

Our results show that divestment decisions are made in the context of simultaneous low profitability of the parent bank and its subsidiary. However, the coefficient of elasticity at means reveals that the probability of foreign asset divestment is significantly higher when the profitability of the parent bank declines compared to the profitability of its subsidiary. A decrease in the parent bank's return on assets by $1 \%$ increases the likelihood of foreign subsidiary divestment by $3.97 \%$, while a decline of the same magnitude in the profitability of 
a subsidiary would increase the likelihood of divestment by only $1.38 \%$. Consequently, our results suggest that the parent bank's profitability weighs more heavily in the decision to divest a foreign subsidiary than does the subsidiary's profitability. Furthermore, we may assume that during financial distress, parent banks divest those subsidiaries that are characterised by low returns. At the same time, they keep their most profitable foreign operations, which can offset future potential losses in the home market.

In the last model, both the host country crisis and the interaction dummy of host and home crises are positive and statistically significant. We assume that a parent bank with financial difficulties in the home market may decide to divest subsidiaries located in countries that are perceived as risky. This divestment allows the parent bank to decrease its overall risk and protect itself from unexpected losses from abroad, which may have resulted in further declines in the bank's profitability. Our assumptions are strengthened by the fact that the interaction dummy of host and home crises is positive and significant.

[Table 6]

In summary, we find clear support for the third hypothesis. Our results reveal that the likelihood of divestment of a foreign operation increases when the parent bank and the subsidiary simultaneously report declining profitability. However, our results show that the results of the parent bank have a greater impact on the divestment decision than do the results of the subsidiary. Therefore, we assume that parent banks that need to improve their profitability will close their nonperforming operations.

Our empirical findings are intuitive and in line with previous studies that conclude that a parent bank's reasons for closing foreign subsidiaries and withdrawing from international markets are driven by problems in the country of origin (Tschoegl, 2004).

However, we cannot rule out the first hypothesis, as the coefficient for profitability of the subsidiary was negative and significant in all of our regressions. The divestment of less profitable operations could also be caused by other factors, such as changes in parent bank strategy or management, which may also result in a short-term decline in the profitability of the parent bank.

\subsection{Sensitivity analysis}

In the previous section, all foreign bank subsidiaries were treated as one group. Thus, an underlying assumption was that all host countries are a relatively homogeneous group during our sample period. However, empirical evidence shows that foreign bank entry motives may differ between developed and developing countries. Indeed, several studies have 
documented that foreign banks are more profitable and more efficient than domestic banks in developing markets (Martinez Peria and Mody, 2004; Bonin et al., 2005; Berger et al., 2009) but are less profitable in industrialised countries (DeYoung and Nolle, 1996; Claessens et al., 2001).

To control for different entry and exit decisions, as well as differences in efficiency, we divided our sample into two subsets: developed and less developed countries. Moreover, within our subsample of developing countries, we excluded a large number of small banks from Luxembourg and Switzerland. Those banks could have biased our results, as we presume that they are engaged mainly in asset management and that their growth is mainly driven by the deposit supply of foreign residents rather than by local macroeconomic developments.

Table 7 presents the regression results for these two subsamples. As expected, we found slightly different results for the two subsets. Our results show that the closure of operations in developing countries is mainly driven by the simultaneous low profitability of the parent bank and its subsidiary. Hence, the results did not differ significantly from our previous findings. All coefficients of interest have the expected signs and remain highly significant.

However, we obtained slightly different results when we used the subsample of developed countries. While the signs of the coefficients of subsidiaries' profitability did not change, they were insignificant in models 1 and 3. In contrast to our previous results, they were significant for the parent bank in model 2. We assume, therefore, that decisions to divest in developed countries are mainly driven by the low profitability of the parent bank; the financial results of the subsidiary in the host country represent a lesser factor in divestment.

In conclusion, using these two subsamples, we documented that exit decisions may differ across countries, which is in line with previous results showing that different factors influence foreign bank entry and efficiency in different host countries.

[Table 7]

\section{Robustness test}

To ensure confidence in our main findings, we ran three sets of robustness checks ${ }^{2}$. The first set kept the exogenous variables and data samples the same as in the main regressions but used a panel model with fixed effects instead of the random model. The second set used the

\footnotetext{
2 These results are available from the author upon request.
} 
main econometric specifications and data samples but altered the specifications of the exogenous variables. The third set used the main econometric specifications and exogenous variables but altered the data samples.

We employed a logit panel model with fixed effects as alternative econometric specifications. The results are weaker but do not change significantly, confirming the poor performance of both the parent bank and its foreign subsidiary as the main cause for exit from abroad.

Turning next to our robustness checks that used alternative specifications of our main exogenous variables, we first employed an interaction variable reflecting the simultaneous profits of the parent and its subsidiary. Second, we ran the variables for profitability separately and also used alternative measures to address the issue of potential multicollinearity. Third, we employed other exogenous variables in the following variations: net loans to customers and short-term funding, liquid assets to total deposits and borrowing, loan loss reserves to gross loans, securities to total assets, non-interest expenditures to total assets, overhead expenses to total assets and net interest revenues to average assets. Finally, we added the bank control variables of asset size and net interest margins. Again, our results chiefly suggest that the main motivations for divestment are most likely to be the low profitability of the subsidiary and problems encountered by the parent bank in the home country.

We finally turned to our robustness checks that altered the data samples. First, we included subsidiaries from European and Latin American regions separately. The results of this data modification were even stronger than our main results when we included only subsidiaries from European countries. The coefficients were also of the same orders of magnitude as those in the main results for all specifications. We further restricted the data sample to the years 1997-2002. All coefficients remained unchanged and significant in almost all instances.

In conclusion, the results of the robustness tests confirm the statistically significant relationship between the closure of an unprofitable foreign bank subsidiary and the probability of financial distress of the parent bank in its home country. Alternative econometric methods, alternative exogenous variable specifications, and alternative data samples all support our core results.

\section{Conclusions}

Our results suggest a clear increase in the probability of closing a subsidiary abroad if the parent bank reported a decrease in profitability prior to the closure event. At the same time, 
we also found evidence of declining profitability for foreign-owned subsidiaries in the year prior to their divestment. However, our results show that the probability of divestment is higher if the parent bank and its subsidiary report decreases in profitability at the same time. Therefore, in our opinion, the foreign bank exit is caused primarily by problems of the parent bank in the home market, which is consistent with data from previous studies. Furthermore, based on our results, we assume that the parent bank probably chooses to sell its least profitable operation, which may aid in mitigating risk and improving profitability.

Our results are strengthened by the fact that we documented that the likelihood of divestment increased during a financial crisis in the home country. However, our results also showed that a parent bank might decide to close an operation in the event of both declining profitability and a financial crisis in the host country. The results for the subsample of developing countries confirmed our main results, which, in our opinion, show that parent banks, due to declining profitability, try to reduce their risk exposure to countries that are perceived as risky. Indeed, we found that the closure of subsidiaries in developed countries was driven only by parent bank problems, while exits from emerging markets were caused by the declining profitability of both parent banks and their subsidiaries.

In the context of the current financial crisis, our results show that the problems of parent banks in developed countries may lead to changes in the structure of the banking sector in developing countries. It remains unclear whether domestic banks from developing countries or new entrants from other developed economies will take advantage of the weakening position of foreign banks from developed countries.

Finally, our results also suggest that, in the future, regulators in the host country should place more emphasis on controlling the parent bank and its standing in its home country. This regulation is important because parent banks may reallocate capital to their home country and disclaim obligations to their subsidiaries abroad. Our study suggests that a worldwide supervision model is needed for multinational banks. This body would be responsible for the supervision of bank holding companies on a consolidation basis, as subsidiaries affect the parent bank's solvency. We believe that the parent bank should not be allowed to relinquish all responsibility for its subsidiary.

The late $19^{\text {th }}$ and early $20^{\text {th }}$ centuries were also characterised by increased foreign banking participation in the domestic banking sectors outside of Europe and North America. According to Goldsmiths (1969), foreign banks at one time suddenly disappeared from host countries, but he did not provide additional details about why this happened. Therefore, we do not know whether the same factors are behind the disinvestment decisions 
of multinational banks today; as a result, their role may decline once again in those countries that have a strong foreign banking presence today. We leave these issues, however, for future studies.

To recapitulate, our research supports the conjecture that there is a significant correlation between the decision to divest foreign operations and the financial performance of a subsidiary and its parent bank. However, our study does not scrutinise the influence of the variation of other subsidiaries and their operations on the short- and long-term financial performance of the parent bank. Hence, this research might be biased by failing to take into account the complexity of interests that are involved in a diversified structure of multinational banks. Consequently, there is still considerable scope for the future study of foreign banks' divestment decisions.

\section{References:}

Bhattacharya, Joydeep (1993). "The Role of Foreign Bank in Developing Countries: A Survey of Evidence.”, Cornell University, mimeo.

Berger, Allen N., and Robert DeYoung (2006). "Technological Progress and the Geographic Expansion of the Banking Industry." Journal of Money, Credit and Banking 38, 1483-1513. Berger, Allen N., Iftekhar Hasan, and Mingming Zhou (2009). "Bank Ownership and Efficiency in China: What Will Happen in the World's Largest Nation?" Journal of Banking and Finance 33, 113-130.

Berger, Allen N., Robert DeYoung, Hesna Genay, and Gregory F. Udell (2000). "The Globalization of Financial Institutions: Evidence from Cross-Border Banking Performance." Brookings-Wharton Papers on Financial Services 3, 23-158.

Bonin, John P, Iftekhar Hasan, and Paul Wachtel (2005). "Privatization Matters: Bank Efficiency in Transition Countries," Journal of Banking and Finance 29(8-9), 2155-2178.

Cerutti E., Dell' Ariccia G. and Soledad Martınez Perı M. (2007). "How Banks Go Abroad: Branches or Subsidiaries?” Journal of Banking and Finance 31, 2007, 1669-1692.

Claessens, Stijn, Asli Demirguc-Kunt, and Harry Huizinga (2001). "How Does Foreign Entry Affect the Domestic Banking Market?" Journal of Banking and Finance 25, 891-911.

Claessens, Stijn and Neeltje Van Horen (2009). "Being a Foreigner Among Domestic Banks: Asset or Liability?" Working Papers WP/09/273, IMF.

Claessens, Stijn, Neeltje Van Horen, Tugba Gurcanlar, and Joaquin Mercado Sapiain (2008). "Foreign Bank Presence in Developing Countries 1995-2006: Data and Trends." mimeo, The World Bank, Washington, D.C. 
Crystal, Jennifer, Dages, Gerard, and Linda Goldberg (2001). "Does Foreign Ownership Contribute to Sounder Banks in Emerging Markets? The Latin American Experience." In R. Litan, P. Masson, and M. Pomerleano, eds.: Open Doors: Foreign Participation in Financial Systems in Developing Countries, Washington D.C.: Brooking Institution Press. Dages, Gerard, Linda Goldberg, and Daniel Kinney (2000). "Foreign and Domestic Bank Participation in Emerging Markets: Lessons from Mexico and Argentina." Federal Reserve Bank of New York Economic Policy Review 6, 17-36.

De Haas, Ralph and Iman van Lelyveld (2006). "Internal Capital Markets and Lending by Multinational Bank Subsidiaries.” Journal of Financial Intermediation 19(1), 1-25.

Denizer, Cevdet (1999). “Foreign Entry in Turkey's Banking Sector, 1980-97.” World Bank Policy Research Working Paper No. 2462.

DeYoung, Robert and Daniel E. Nolle (1996). "Foreign-Owned Banks in the United States :

Earning Market Share or Buying It?” Journal of Money, Credit, and Banking, 28, 622-636. Engwall Lars, Rolf Marquardt, Torben Pedersen, and Adrian E. Tschoegl (2001) "Foreign Bank Penetration of Newly Opened Markets in the Nordic Countries" Journal of International Financial Markets, Institutions and Money 11, 2001, 53-63.

Focarelli, Dario and Alberto F. Pozzolo (2005). "Where do Banks Expand Abroad? An Empirical Analysis.” Journal of Business 78, 2435-2463.

Giannetti, Mariassunta and Steven Ongena (2009). "Financial Integration and Firm Performance: Evidence from Foreign Bank Entry in Emerging Markets." Review of Finance $13,181-223$.

Goldsmith R.W. (1969). Financial Structure and Development. New Haven: Yale University Press.

Gormley, Todd A. (2010). “The Impact of Foreign Bank Entry in Emerging Markets:

Evidence from India.” Journal of Financial Intermediation 19, 26-51.

Guillen, Mauro F., and Adrian E. Tschoegl (2000). “The Internationalization of Retail Banking. The Case of Spanish Banks in Latin America." Transnational Corporation 9(3), 63-97.

Laeven, Luc and Fabian Valencia (2008). "Systemic Banking Crises: A New Database." IMF Working Paper.

Leveen, Serpil, and John Praveen (1994). "A Disaggregated Approach to the Analysis of the Effects of Bank Foreign Ownership on Bank Performance.” Journal of Applied Business Research 10, 121-129. 
Martinez Peria, Maria Soledad and Ashoka Mody (2004). "How Foreign Participation and Market Concentration Impact Bank Spreads: Evidence from Latin America," Journal of Money, Credit and Banking 36, 511-37.

Micco, Alejandro, Ugo Panizza and Monica Yañez (2007). "Bank Ownership and Performance. Does Politics Matter?” Journal of Banking and Finance 31, 219-241.

Tschoegl, Adrian E. (2005). "Financial Crises and Presence of Foreign Banks" In P. Honohan and L. Laeven, eds. Systemic Financial Distress: Containment and Resolution, Cambridge: Cambridge University Press.

Tschoegl, Adrian E. (2004). "The California Subsidiaries of Japanese Banks: A Genealogical History." Journal of Asian Business 20, 59-82.

Peek, Joe, and Eric S. Rosengren (2000). "Collateral Damage: Effects of the Japanese Bank Crisis on Real Activity in the United States.” American Economic Review 90, 2000, 30-45. Williams, Barry (1996). "Determinants of the Performance of Japanese Financial Institutions in Australia 1987-1992." Applied Economics 28, 1153-1165.

Williams, Barry (2003). "Domestic and international determinants of bank profits: Foreign banks in Australia." Journal of Banking and Finance 27, 1185-1210.

Wheelock, David C., and Paul W. Wilson (2000). "Why Do Banks Disappear? The Determinants of U.S. Bank Failures and Acquisitions." The Review of Economics and Statistics 82, 127-138. 
Table 1

Number of foreign bank subsidiary divestments by host country and year

\begin{tabular}{|c|c|c|c|c|c|c|c|c|c|c|c|c|c|c|}
\hline Countries & 1997 & 1998 & 1999 & 2000 & 2001 & 2002 & 2003 & 2004 & 2005 & 2006 & 2007 & 2008 & 2009 & Total \\
\hline ALGERIA & & & & & & & & & & & & & 1 & 1 \\
\hline ARGENTINA & & 1 & & & & 4 & 1 & 1 & 1 & 1 & 1 & & 1 & 11 \\
\hline AUSTRALIA & & 1 & & & & & & & & & & 1 & & 2 \\
\hline AUSTRIA & & 1 & 1 & & 1 & & & & & & & & 2 & 5 \\
\hline BELGIUM & & & 1 & & & & & 1 & 1 & & & & & 3 \\
\hline BOLIVIA & & & & & & & & & & 1 & & & & 1 \\
\hline BRAZIL & & & & 2 & & 1 & 4 & & & 1 & & & & 8 \\
\hline BULGARIA & & & & 1 & & & & & & & & & & 1 \\
\hline CANADA & & & & & & & & 1 & 1 & & & & & 2 \\
\hline CHILE & & & & & & & 1 & & & 1 & & & & 2 \\
\hline COLOMBIA & & & & & & & 1 & & 1 & & & & & 2 \\
\hline CROATIA & & & & & & & 1 & & & 1 & & & & 2 \\
\hline CZECH REPUBLIC & & & & & & 1 & 1 & 1 & & 1 & & 1 & & 5 \\
\hline DENMARK & & & & & & & & 1 & 1 & & & & & 2 \\
\hline EL SALVADOR & & & & & & & & & & & 1 & & & 1 \\
\hline FRANCE & & & & & & 1 & 2 & 1 & & 1 & 1 & & & 6 \\
\hline GERMANY & & 1 & 1 & & & & 1 & & & & & 1 & & 4 \\
\hline GUATEMALA & & & & & & & 1 & & & & 1 & & & 2 \\
\hline HONDURAS & & & & & & & 1 & & & & 1 & & & 2 \\
\hline HONG KONG & & & & & & & 1 & 2 & & & & & & 3 \\
\hline HUNGARY & & 1 & & 1 & 1 & & 1 & & & 1 & & & & 5 \\
\hline INDONESIA & & & & 1 & 3 & 1 & 2 & & & & & & & 7 \\
\hline IRELAND & & & & & & & & & 1 & & & & & 1 \\
\hline ISRAEL & & & & & & & & 1 & & & & & & 1 \\
\hline ITALY & & & & & & & & & & & & 3 & & 3 \\
\hline JAPAN & & & & & & 1 & & & & & & 1 & & 2 \\
\hline KENYA & & & & & 1 & & & & & & & & & 1 \\
\hline KYRGYZSTAN & & & & 1 & & & & & & & & & & 1 \\
\hline LATVIA & & & & & 1 & & & & & & & & & 1 \\
\hline LUXEMBOURG & & & & & 2 & 1 & & 1 & & & 1 & & & 5 \\
\hline MEXICO & & & & & & & 1 & & & & & & & 1 \\
\hline NETHERLANDS & & & & & & & 1 & & & & & & & 1 \\
\hline NEW ZEALAND & & & & & & & 1 & & & & & & & 1 \\
\hline NORWAY & & & & & & & & & & & & 1 & & 1 \\
\hline PANAMA & & & & 1 & 2 & & 1 & & & 1 & 1 & & & 6 \\
\hline PARAGUAY & & & & & & & & 1 & & 1 & 1 & 1 & & 4 \\
\hline PERU & & & & & & & & & & 1 & & & & 1 \\
\hline PHILIPPINES & & & & 1 & & & & & & & & & & 1 \\
\hline POLAND & & & & & & 2 & 1 & & & & & & & 3 \\
\hline PORTUGAL & & & & & 1 & & & & & & & & & 1 \\
\hline ROMANIA & & & & 2 & 1 & & & & 1 & & & & & 4 \\
\hline SINGAPORE & & & & & & & & & & & & & 1 & 1 \\
\hline SLOVAKIA & & & & & & & & & & & 1 & & & 1 \\
\hline SPAIN & 1 & 2 & 1 & & & & 1 & & & & & & & 5 \\
\hline SURINAME & & & & & 1 & & & & & & & & & 1 \\
\hline SWITZERLAND & & & & 1 & 2 & & 1 & 1 & & & 1 & & 3 & 9 \\
\hline THAILAND & & & & & & & & 1 & & & & & & 1 \\
\hline TURKEY & & & 1 & & & & & & & & & & & 1 \\
\hline UKRAINE & & & & & & & & 1 & & 1 & & & & 2 \\
\hline UNITED KINGDOM & & & & & & & & & 1 & 1 & & & & 2 \\
\hline URUGUAY & & & & & & & 2 & & & 1 & & & & 3 \\
\hline USA & & & & & 2 & 1 & 1 & & & & & & & 4 \\
\hline UZBEKISTAN & & & & & & & & & & 1 & & & & 1 \\
\hline VENEZUELA & & & & & & 1 & & & & 1 & & & & 2 \\
\hline TOTAL & 1 & 7 & 5 & 11 & 18 & 14 & 28 & 14 & 8 & 16 & 10 & 9 & 8 & 149 \\
\hline
\end{tabular}


Table 2

Number of foreign bank subsidiary divestments by home country and year

\begin{tabular}{|c|c|c|c|c|c|c|c|c|c|c|c|c|c|c|}
\hline Countries & 1997 & 1998 & 1999 & 2000 & 2001 & 2002 & 2003 & 2004 & 2005 & 2006 & 2007 & 2008 & 2009 & Total \\
\hline AUSTRALIA & & & & & 1 & & & & 2 & & & & & 3 \\
\hline AUSTRIA & & & & & 1 & & & & & 1 & 1 & 1 & & 4 \\
\hline BAHRAIN & & & & & & & 1 & 1 & & & & & & 2 \\
\hline BELGIUM & & & & & 1 & 1 & & 1 & & & & & & 3 \\
\hline BRAZIL & & & & & 1 & & & & & & & & & 1 \\
\hline CANADA & & & & & & 1 & & & & & & & & 1 \\
\hline CHILE & & & & & & & & & & 1 & & & & 1 \\
\hline COSTA RICA & & & & & & & & & & & 4 & & & 4 \\
\hline \multicolumn{2}{|c|}{ CZECH REPUBLIC } & & & & & 1 & & & & & & & & 1 \\
\hline DENMARK & & & & & 1 & & & & & & & & & 1 \\
\hline ECUADOR & & & & & 1 & & & & & & & & & 1 \\
\hline ESTONIA & & & & & 1 & & & & & & & & & 1 \\
\hline FRANCE & & 2 & 1 & & 3 & 1 & 1 & 1 & 1 & 1 & & & 2 & 13 \\
\hline GERMANY & & 1 & & 1 & & 2 & 3 & 1 & & 2 & & & 4 & 14 \\
\hline GREECE & & & & & & & & & 1 & & & & & 1 \\
\hline HONG KONG & & & & 1 & & & & & & & & & & 1 \\
\hline HUNGARY & & & & 1 & & & & & & & & & & 1 \\
\hline ICELAND & & & & & & & & 1 & & & & 1 & & 2 \\
\hline IRELAND & & & & & & & 1 & & & & 1 & & & 2 \\
\hline ITALY & 1 & 2 & & & & 2 & 9 & 3 & & 2 & & & & 19 \\
\hline JAPAN & & & 1 & 1 & 1 & 1 & 2 & & & & & & & 6 \\
\hline \multicolumn{2}{|c|}{ KOREA REPUBLIC } & & & & & 1 & 1 & & 1 & 1 & & & & 4 \\
\hline \multicolumn{2}{|c|}{ LUXEMBOURG } & & & & & & & & & & 1 & & & 1 \\
\hline MEXICO & & & & & & 1 & & & & & & & & 1 \\
\hline \multicolumn{2}{|c|}{ NETHERLANDS } & & & 1 & 5 & & 1 & 2 & 1 & & & 1 & 2 & 13 \\
\hline NORWAY & & & & & & & & & 1 & & & & & 1 \\
\hline POLAND & & & & & 1 & & & 1 & & & & & & 2 \\
\hline PORTUGAL & & & & 1 & & & & & & 1 & & & & 2 \\
\hline \multicolumn{2}{|c|}{ SOUTH AFRICA } & & & & & & & 1 & & & & & & 1 \\
\hline SPAIN & & & & & & 1 & 1 & & & 2 & & 2 & & 6 \\
\hline \multicolumn{2}{|c|}{ SWITZERLAND } & & & & & & & & & & 1 & 1 & & 2 \\
\hline TURKEY & & & 1 & 3 & 1 & & 1 & & & 1 & & & & 7 \\
\hline \multicolumn{2}{|c|}{ UNITED KINGDOM } & 1 & 2 & & & & 6 & 1 & 1 & 1 & 1 & 1 & & 14 \\
\hline USA & & 1 & & 2 & & 2 & 1 & 1 & & 3 & 1 & 2 & & 13 \\
\hline TOTAL & 1 & 7 & 5 & 11 & 18 & 14 & 28 & 14 & 8 & 16 & 10 & 9 & 8 & 149 \\
\hline
\end{tabular}


Table 3

Summary statistics of the parent bank and its foreign subsidiary one year prior to divestment

\begin{tabular}{|l|c|c|c|c|c|}
\hline & \multicolumn{2}{|c|}{ Foreign Bank Subsidiary } & \multicolumn{2}{c|}{ Parent Bank } & \\
\hline & Mean & Std. Dev. & Mean & Std. Dev. & t-Stat. \\
\hline Profitability & -0.001 & 0.005 & 0.002 & 0.002 & $-2.331^{\text {**** }}$ \\
\hline Equity & 0.118 & 0.009 & 0.067 & 0.008 & 0.800 \\
\hline Loans & 0.498 & 0.030 & 0.482 & 0.026 & 0.138 \\
\hline Asset Quality & 0.217 & 0.120 & 0.390 & 0.073 & -1.094 \\
\hline Liquidity & 0.142 & 0.027 & 0.185 & 0.024 & $-1.825^{* *}$ \\
\hline
\end{tabular}

*, **, and *** indicate significant differences between the divested foreign bank subsidiary's and parent bank's mean values at the $10 \%, 5 \%$ and $1 \%$ levels, respectively. 
Table 4

Foreign Bank Subsidiary Characteristics

Probit estimations of the likelihood that a foreign bank subsidiary will be divested by its parent bank

\begin{tabular}{|c|c|c|c|c|c|c|c|}
\hline & (1) & (2) & (3) & (4) & $(5)$ & (6) & $\mathrm{dy} / \mathrm{dx}$ \\
\hline Profitability & $\begin{array}{c}-4.129^{* *} \\
(1.781)\end{array}$ & $\begin{array}{c}-4.237^{* *} \\
(1.787)\end{array}$ & $\begin{array}{c}-3.615^{* *} \\
(1.823)\end{array}$ & $\begin{array}{c}-3.628^{* *} \\
(1.818)\end{array}$ & $\begin{array}{c}-3.588^{* *} \\
(1.822)\end{array}$ & $\begin{array}{c}-3.768^{* *} \\
(1.843)\end{array}$ & -0.60 \\
\hline Equity & $\begin{array}{c}0.532 \\
(0.875)\end{array}$ & $\begin{array}{c}0.587 \\
(0.882)\end{array}$ & $\begin{array}{c}0.646 \\
(0.885)\end{array}$ & $\begin{array}{c}0.521 \\
(0.892)\end{array}$ & $\begin{array}{c}0.500 \\
(0.897)\end{array}$ & $\begin{array}{c}0.451 \\
(0.919)\end{array}$ & 0.07 \\
\hline Loans & $\begin{array}{c}0.350 \\
(0.332)\end{array}$ & $\begin{array}{c}0.400 \\
(0.336)\end{array}$ & $\begin{array}{c}0.410 \\
(0.338)\end{array}$ & $\begin{array}{c}0.365 \\
(0.343)\end{array}$ & $\begin{array}{c}0.358 \\
(0.344)\end{array}$ & $\begin{array}{c}0.395 \\
(0.365)\end{array}$ & 0.06 \\
\hline Asset quality & $\begin{array}{l}-0.187^{*} \\
(0.110)\end{array}$ & $\begin{array}{l}-0.193^{*} \\
(0.112)\end{array}$ & $\begin{array}{l}-0.205^{*} \\
(0.112)\end{array}$ & $\begin{array}{l}-0.206^{*} \\
(0.114)\end{array}$ & $\begin{array}{l}-0.206^{*} \\
(0.114)\end{array}$ & $\begin{array}{l}-0.208^{*} \\
(0.115)\end{array}$ & -0.03 \\
\hline Liquidity & $\begin{array}{l}-0.579 \\
(0.378)\end{array}$ & $\begin{array}{l}-0.504 \\
(0.375)\end{array}$ & $\begin{array}{l}-0.530 \\
(0.379)\end{array}$ & $\begin{array}{l}-0.524 \\
(0.375)\end{array}$ & $\begin{array}{l}-0.495 \\
(0.383)\end{array}$ & $\begin{array}{c}-0.550 \\
(0.394)\end{array}$ & -0.09 \\
\hline Government & & $\begin{array}{l}1.194^{* * * *} \\
(0.394)\end{array}$ & $\begin{array}{c}1.202^{* * * *} \\
(0.397)\end{array}$ & $\begin{array}{c}1.167^{* * * *} \\
(0.398)\end{array}$ & $\begin{array}{c}1.180^{* * * *} \\
(0.399)\end{array}$ & $\begin{array}{l}1.164^{* * * *} \\
(0.404)\end{array}$ & $0.33^{\mathrm{a}}$ \\
\hline Host Crisis & & & $\begin{array}{c}0.356 \\
(0.223)\end{array}$ & $\begin{array}{c}0.278 \\
(0.229)\end{array}$ & $\begin{array}{c}0.273 \\
(0.229)\end{array}$ & $\begin{array}{c}0.343 \\
(0.236)\end{array}$ & $0.07^{\mathrm{a}}$ \\
\hline LDC & & & & $\begin{array}{c}0.200 \\
(0.153)\end{array}$ & $\begin{array}{c}0.186 \\
(0.159)\end{array}$ & $\begin{array}{l}0.315^{*} \\
(0.187)\end{array}$ & $0.05^{\mathrm{a}}$ \\
\hline Distance & & & & & $\begin{array}{l}-0.053 \\
(0.156)\end{array}$ & $\begin{array}{c}-0.298 \\
(0.216)\end{array}$ & $-0.05^{\mathrm{a}}$ \\
\hline Asia \& Australia & & & & & & $\begin{array}{l}-0.070 \\
(0.320)\end{array}$ & $-0.01^{\mathrm{a}}$ \\
\hline Europe & & & & & & $\begin{array}{c}0.214 \\
(0.293)\end{array}$ & $0.03^{\mathrm{a}}$ \\
\hline Latin America & & & & & & $\begin{array}{l}-0.255 \\
(0.309)\end{array}$ & $-0.04^{\mathrm{a}}$ \\
\hline Constant & $\begin{array}{c}-1.339^{* * *} \\
(0.219)\end{array}$ & $\begin{array}{c}-1.417^{* * *} \\
(0.223)\end{array}$ & $\begin{array}{c}-1.463^{* * * *} \\
(0.227)\end{array}$ & $\begin{array}{c}-1.536^{* * * *} \\
(0.236)\end{array}$ & $\begin{array}{c}-1.501^{* * *} \\
(0.258)\end{array}$ & $\begin{array}{c}-1.485^{* * *} \\
(0.332)\end{array}$ & \\
\hline $\mathrm{N}$ & 631 & 631 & 631 & 631 & 631 & 631 & \\
\hline Log likelihood & -204.07 & -199.72 & -198.54 & -197.70 & -197.64 & -196.22 & \\
\hline Wald $\chi^{2}$ & 11.429 & 20.562 & 22.797 & 24.332 & 24.417 & 26.779 & \\
\hline
\end{tabular}

${ }^{\mathrm{a}} \mathrm{dy} / \mathrm{dx}$ represents the discrete change in the dummy variable from 0 to 1 .

Robust standard errors are shown in parentheses. *,**, and *** denote significance at the $10 \%, 5 \%$ and $1 \%$ levels, respectively. 
Table 5

Parent Bank Characteristics

Probit estimations of the likelihood that a foreign bank subsidiary will be divested by its parent bank

\begin{tabular}{|c|c|c|c|c|c|c|}
\hline & (1) & (2) & (3) & (4) & (5) & $\mathrm{dy} / \mathrm{dx}$ \\
\hline Profitability & $\begin{array}{c}-6.871 \\
(4.884)\end{array}$ & $\begin{array}{c}-6.723 \\
(4.878)\end{array}$ & $\begin{array}{c}-6.751 \\
(4.929)\end{array}$ & $\begin{array}{l}-7.379 \\
(5.008)\end{array}$ & $\begin{array}{l}-7.409 \\
(5.038)\end{array}$ & -1.67 \\
\hline Equity & $\begin{array}{c}-0.745 \\
(1.021)\end{array}$ & $\begin{array}{c}-0.672 \\
(1.020)\end{array}$ & $\begin{array}{c}-0.755 \\
(1.029)\end{array}$ & $\begin{array}{l}-0.957 \\
(1.054)\end{array}$ & $\begin{array}{c}-0.935 \\
(1.077)\end{array}$ & -0.21 \\
\hline Loans & $\begin{array}{l}-0.150 \\
(0.404)\end{array}$ & $\begin{array}{l}-0.129 \\
(0.403)\end{array}$ & $\begin{array}{l}-0.260 \\
(0.413)\end{array}$ & $\begin{array}{l}-0.297 \\
(0.415)\end{array}$ & $\begin{array}{l}-0.213 \\
(0.422)\end{array}$ & -0.05 \\
\hline Asset quality & $\begin{array}{c}-0.034 \\
(0.100)\end{array}$ & $\begin{array}{l}-0.030 \\
(0.100)\end{array}$ & $\begin{array}{c}-0.074 \\
(0.099)\end{array}$ & $\begin{array}{l}-0.076 \\
(0.101)\end{array}$ & $\begin{array}{l}-0.073 \\
(0.102)\end{array}$ & -0.01 \\
\hline Liquidity & $\begin{array}{c}0.587 \\
(0.380)\end{array}$ & $\begin{array}{c}0.562 \\
(0.379)\end{array}$ & $\begin{array}{c}0.626 \\
(0.381)\end{array}$ & $\begin{array}{l}0.720^{*} \\
(0.391)\end{array}$ & $\begin{array}{c}0.617 \\
(0.406)\end{array}$ & 0.14 \\
\hline Government & & $\begin{array}{c}0.238 \\
(0.285)\end{array}$ & $\begin{array}{c}0.212 \\
(0.289)\end{array}$ & $\begin{array}{c}0.188 \\
(0.288)\end{array}$ & $\begin{array}{c}0.171 \\
(0.297)\end{array}$ & $0.04^{\mathrm{a}}$ \\
\hline Home Crisis & & & $\begin{array}{l}0.467^{* *} \\
(0.220)\end{array}$ & $\begin{array}{l}0.497^{* *} \\
(0.222)\end{array}$ & $\begin{array}{l}0.606^{* *} \\
(0.261)\end{array}$ & $0.17^{\mathrm{a}}$ \\
\hline Distance & & & & $\begin{array}{l}-0.164 \\
(0.140)\end{array}$ & $\begin{array}{c}-0.242 \\
(0.161)\end{array}$ & $-0.06^{\mathrm{a}}$ \\
\hline Asia \& Australia & & & & & $\begin{array}{c}-0.063 \\
(0.302)\end{array}$ & $-0.01^{\mathrm{a}}$ \\
\hline Europe & & & & & $\begin{array}{c}0.200 \\
(0.212)\end{array}$ & $0.04^{\mathrm{a}}$ \\
\hline Latin America & & & & & $\begin{array}{c}0.317 \\
(0.536)\end{array}$ & $0.08^{\mathrm{a}}$ \\
\hline Constant & $\begin{array}{c}-0.962^{* * * *} \\
(0.252)\end{array}$ & $\begin{array}{c}-0.988^{* * *} \\
(0.252)\end{array}$ & $\begin{array}{c}-0.972^{* * *} \\
(0.255) \\
\end{array}$ & $\begin{array}{c}-0.863^{* * * *} \\
(0.272) \\
\end{array}$ & $\begin{array}{c}-0.991^{* * * *} \\
(0.307) \\
\end{array}$ & \\
\hline $\mathrm{N}$ & 576 & 576 & 576 & 576 & 576 & \\
\hline Log likelihood & -242.78 & -242.15 & -237.86 & -237.34 & -236.76 & \\
\hline Wald $\chi^{2}$ & 5.404 & 6.054 & 11.340 & 12.525 & 14.163 & \\
\hline
\end{tabular}

a dy/dx represents discrete change in the dummy variable from 0 to 1 .

Robust standard errors are shown in parentheses. *,**, and *** denote significance at the $10 \%, 5 \%$ and $1 \%$ levels, respectively. 
Table 6

Subsidiary and Parent Bank Characteristics

Probit estimations of the likelihood that a foreign bank subsidiary will be divested by its parent bank

\begin{tabular}{|c|c|c|c|c|c|c|c|c|}
\hline & (1) & $(2)$ & (3) & (4) & (5) & (6) & (7) & $\mathrm{dy} / \mathrm{dx}$ \\
\hline \multicolumn{9}{|c|}{ Foreign bank subsidiary characteristics } \\
\hline Profitability & $\begin{array}{l}-6.882^{* *} \\
(3.317)\end{array}$ & $\begin{array}{l}-6.801^{* *} \\
(3.341)\end{array}$ & $\begin{array}{l}-6.480^{*} \\
(3.309)\end{array}$ & $\begin{array}{c}-7.158^{* *} \\
(3.428)\end{array}$ & $\begin{array}{c}-7.385^{* *} \\
(3.396)\end{array}$ & $\begin{array}{c}-7.652^{* *} \\
(3.403)\end{array}$ & $\begin{array}{c}-7.369^{* *} \\
(3.400)\end{array}$ & -1.38 \\
\hline Equity & $\begin{array}{c}0.941 \\
(1.060)\end{array}$ & $\begin{array}{c}1.016 \\
(1.066)\end{array}$ & $\begin{array}{c}1.165 \\
(1.069)\end{array}$ & $\begin{array}{c}0.861 \\
(1.094)\end{array}$ & $\begin{array}{c}1.008 \\
(1.084)\end{array}$ & $\begin{array}{c}1.066 \\
(1.096)\end{array}$ & $\begin{array}{c}1.171 \\
(1.116)\end{array}$ & 0.22 \\
\hline Loans & $\begin{array}{c}0.252 \\
(0.428)\end{array}$ & $\begin{array}{c}0.237 \\
(0.435)\end{array}$ & $\begin{array}{c}0.182 \\
(0.437)\end{array}$ & $\begin{array}{c}0.327 \\
(0.459)\end{array}$ & $\begin{array}{c}0.302 \\
(0.447)\end{array}$ & $\begin{array}{c}0.327 \\
(0.465)\end{array}$ & $\begin{array}{c}0.307 \\
(0.469)\end{array}$ & 0.06 \\
\hline $\begin{array}{l}\text { Asset } \\
\text { quality }\end{array}$ & $\begin{array}{c}-0.194 \\
(0.165)\end{array}$ & $\begin{array}{l}-0.211 \\
(0.172)\end{array}$ & $\begin{array}{c}-0.299 \\
(0.190)\end{array}$ & $\begin{array}{l}-0.208 \\
(0.172)\end{array}$ & $\begin{array}{c}-0.246 \\
(0.183)\end{array}$ & $\begin{array}{c}-0.251 \\
(0.184)\end{array}$ & $\begin{array}{c}-0.262 \\
(0.189)\end{array}$ & -0.05 \\
\hline Liquidity & $\begin{array}{l}-0.610 \\
(0.438)\end{array}$ & $\begin{array}{l}-0.557 \\
(0.434)\end{array}$ & $\begin{array}{c}-0.651 \\
(0.445)\end{array}$ & $\begin{array}{l}-0.511 \\
(0.411)\end{array}$ & $\begin{array}{c}-0.592 \\
(0.428)\end{array}$ & $\begin{array}{l}-0.618 \\
(0.433)\end{array}$ & $\begin{array}{l}-0.564 \\
(0.439)\end{array}$ & -0.11 \\
\hline \multicolumn{9}{|c|}{ Parent bank characteristics } \\
\hline Profitability & $\begin{array}{c}-17.11^{* *} \\
(8.296)\end{array}$ & $\begin{array}{c}-18.44^{* *} \\
(8.507)\end{array}$ & $\begin{array}{c}-19.17^{* *} \\
(8.677)\end{array}$ & $\begin{array}{c}-22.11^{* *} \\
(8.970)\end{array}$ & $\begin{array}{c}-22.30^{* *} \\
(9.112)\end{array}$ & $\begin{array}{c}-20.35^{* *} \\
(9.112)\end{array}$ & $\begin{array}{c}-21.15^{* *} \\
(9.279)\end{array}$ & -3.97 \\
\hline Equity & $\begin{array}{c}-0.170 \\
(1.478)\end{array}$ & $\begin{array}{c}-0.016 \\
(1.513)\end{array}$ & $\begin{array}{c}0.018 \\
(1.513)\end{array}$ & $\begin{array}{c}0.055 \\
(1.539)\end{array}$ & $\begin{array}{c}0.111 \\
(1.535)\end{array}$ & $\begin{array}{c}-0.368 \\
(1.583)\end{array}$ & $\begin{array}{l}-0.678 \\
(1.625)\end{array}$ & -0.13 \\
\hline Loans & $\begin{array}{c}0.006 \\
(0.572)\end{array}$ & $\begin{array}{c}0.125 \\
(0.586)\end{array}$ & $\begin{array}{c}0.161 \\
(0.587)\end{array}$ & $\begin{array}{c}0.090 \\
(0.600)\end{array}$ & $\begin{array}{c}0.074 \\
(0.593)\end{array}$ & $\begin{array}{c}-0.108 \\
(0.605)\end{array}$ & $\begin{array}{l}-0.146 \\
(0.609)\end{array}$ & -0.03 \\
\hline $\begin{array}{l}\text { Asset } \\
\text { quality }\end{array}$ & $\begin{array}{l}-0.115 \\
(0.157)\end{array}$ & $\begin{array}{l}-0.114 \\
(0.158)\end{array}$ & $\begin{array}{c}-0.149 \\
(0.168)\end{array}$ & $\begin{array}{c}-0.167 \\
(0.165)\end{array}$ & $\begin{array}{l}-0.204 \\
(0.176)\end{array}$ & $\begin{array}{l}-0.184 \\
(0.179)\end{array}$ & $\begin{array}{c}-0.181 \\
(0.182)\end{array}$ & -0.03 \\
\hline Liquidity & $\begin{array}{c}0.283 \\
(0.518)\end{array}$ & $\begin{array}{c}0.253 \\
(0.533)\end{array}$ & $\begin{array}{c}0.356 \\
(0.534)\end{array}$ & $\begin{array}{c}0.308 \\
(0.545)\end{array}$ & $\begin{array}{c}0.320 \\
(0.537)\end{array}$ & $\begin{array}{c}0.386 \\
(0.535)\end{array}$ & $\begin{array}{c}0.451 \\
(0.542)\end{array}$ & 0.08 \\
\hline Government & & $\begin{array}{l}1.054^{* *} \\
(0.441)\end{array}$ & $\begin{array}{l}1.069^{* *} \\
(0.448)\end{array}$ & $\begin{array}{l}1.094^{* *} \\
(0.443)\end{array}$ & $\begin{array}{l}1.108^{* *} \\
(0.442)\end{array}$ & $\begin{array}{l}1.053^{* *} \\
(0.449)\end{array}$ & $\begin{array}{l}1.078^{* *} \\
(0.449)\end{array}$ & $0.32^{\mathrm{a}}$ \\
\hline Host Crisis & & & $\begin{array}{c}0.530^{*} \\
(0.301)\end{array}$ & & & & & \\
\hline Home Crisis & & & & $\begin{array}{c}0.147 \\
(0.329)\end{array}$ & & & & \\
\hline $\begin{array}{l}\text { Host*Home } \\
\text { Crisis }\end{array}$ & & & & & $\begin{array}{c}0.844^{*} \\
(0.489)\end{array}$ & $\begin{array}{c}0.838^{*} \\
(0.484)\end{array}$ & $\begin{array}{c}0.949^{*} \\
(0.497)\end{array}$ & $0.28^{\mathrm{a}}$ \\
\hline LDC & & & & & & $\begin{array}{c}0.316 \\
(0.195)\end{array}$ & $\begin{array}{c}0.262 \\
(0.202)\end{array}$ & $0.05^{\mathrm{a}}$ \\
\hline Distance & & & & & & & $\begin{array}{c}-0.237 \\
(0.205)\end{array}$ & $\underset{\mathrm{a}}{-0.05}$ \\
\hline Constant & $\begin{array}{c}-1.061^{* *} \\
(0.428)\end{array}$ & $\begin{array}{c}-1.167^{* * *} \\
(0.440)\end{array}$ & $\begin{array}{c}-1.202^{* * *} \\
(0.441)\end{array}$ & $\begin{array}{c}-1.201^{* * *} \\
(0.453)\end{array}$ & $\begin{array}{c}-1.180^{* * *} \\
(0.448)\end{array}$ & $\begin{array}{c}-1.284^{* * *} \\
(0.461)\end{array}$ & $\begin{array}{c}-1.106^{* *} \\
(0.492)\end{array}$ & \\
\hline $\mathrm{N}$ & 344 & 344 & 344 & 344 & 344 & 344 & 344 & \\
\hline $\begin{array}{l}\text { Log } \\
\text { likelihood }\end{array}$ & -130.70 & -128.15 & -126.60 & -125.07 & -123.59 & -122.41 & -121.78 & \\
\hline Wald $\chi^{2}$ & 12.075 & 17.289 & 19.692 & 18.935 & 21.444 & 23.743 & 24.573 & \\
\hline
\end{tabular}

${ }^{\mathrm{a}} \mathrm{dy} / \mathrm{dx}$ represents discrete change in the dummy variable from 0 to 1 .

Robust standard errors are shown in parentheses. *, **, and *** denote significance at the $10 \%, 5 \%$ and $1 \%$ levels, respectively. 
Table 7

Developed and Developing Countries

Probit estimations of the likelihood that a foreign bank subsidiary will be divested by its parent bank

\begin{tabular}{|c|c|c|c|c|c|c|c|c|}
\hline & \multicolumn{3}{|c|}{ Developing countries } & \multicolumn{5}{|c|}{ Developed Countries } \\
\hline & (1) & $(2)$ & (3) & $\mathrm{dy} / \mathrm{dx}$ & $(1)$ & (2) & (3) & $\mathrm{dy} / \mathrm{dx}$ \\
\hline & \multicolumn{8}{|c|}{ Foreign bank subsidiary characteristics } \\
\hline Profitability & $\begin{array}{l}-3.261^{*} \\
(1.959)\end{array}$ & & $\begin{array}{l}-8.314^{*} \\
(4.952)\end{array}$ & -1.81 & $\begin{array}{l}-7.451 \\
(5.905)\end{array}$ & & $\begin{array}{l}-9.948 \\
(7.489)\end{array}$ & -1.33 \\
\hline Equity & $\begin{array}{l}-0.021 \\
(1.086)\end{array}$ & & $\begin{array}{c}0.761 \\
(1.600)\end{array}$ & 0.17 & $\begin{array}{c}2.159 \\
(1.838)\end{array}$ & & $\begin{array}{c}0.219 \\
(2.577)\end{array}$ & 0.03 \\
\hline Loans & $\begin{array}{c}0.207 \\
(0.502)\end{array}$ & & $\begin{array}{c}0.311 \\
(0.758)\end{array}$ & 0.07 & $\begin{array}{c}0.509 \\
(0.494)\end{array}$ & & $\begin{array}{c}0.052 \\
(0.721)\end{array}$ & 0.01 \\
\hline $\begin{array}{l}\text { Asset } \\
\text { quality }\end{array}$ & $\begin{array}{l}-0.344^{* *} \\
(0.167)\end{array}$ & & $\begin{array}{l}-0.519 \\
(0.329)\end{array}$ & -0.11 & $\begin{array}{l}-0.046 \\
(0.164)\end{array}$ & & $\begin{array}{c}0.031 \\
(0.166)\end{array}$ & 0.00 \\
\hline \multirow[t]{2}{*}{ Liquidity } & $\begin{array}{l}-0.319 \\
(0.393)\end{array}$ & & $\begin{array}{l}-0.685 \\
(0.579)\end{array}$ & -0.15 & $\begin{array}{c}-1.964^{* *} \\
(0.904)\end{array}$ & & $\begin{array}{c}-0.883 \\
(1.146)\end{array}$ & -0.12 \\
\hline & \multicolumn{8}{|c|}{ Parent bank characteristics } \\
\hline Profitability & & $\begin{array}{c}-3.916 \\
(5.859)\end{array}$ & $\begin{array}{c}-18.357^{*} \\
(9.725)\end{array}$ & -4.01 & & $\begin{array}{c}-33.164^{* *} \\
(16.536)\end{array}$ & $\begin{array}{l}-18.573 \\
(30.911)\end{array}$ & -2.49 \\
\hline Equity & & $\begin{array}{c}-1.761 \\
(1.332)\end{array}$ & $\begin{array}{l}-1.856 \\
(2.043)\end{array}$ & -0.41 & & $\begin{array}{c}2.203 \\
(2.272)\end{array}$ & $\begin{array}{c}0.461 \\
(4.480)\end{array}$ & 0.06 \\
\hline Loans & & $\begin{array}{l}-0.934^{*} \\
(0.544)\end{array}$ & $\begin{array}{l}-1.389^{*} \\
(0.770)\end{array}$ & -0.30 & & $\begin{array}{l}1.629^{* * *} \\
(0.785)\end{array}$ & $\begin{array}{l}3.059^{*} \\
(1.603)\end{array}$ & 0.41 \\
\hline $\begin{array}{l}\text { Asset } \\
\text { quality }\end{array}$ & & $\begin{array}{c}0.057 \\
(0.142)\end{array}$ & $\begin{array}{l}-0.040 \\
(0.224)\end{array}$ & -0.00 & & $\begin{array}{l}-0.751^{*} \\
(0.422)\end{array}$ & $\begin{array}{c}-0.171 \\
(0.439)\end{array}$ & -0.02 \\
\hline Liquidity & & $\begin{array}{c}0.453 \\
(0.490)\end{array}$ & $\begin{array}{c}0.668 \\
(0.617)\end{array}$ & 0.15 & & $\begin{array}{l}1.718^{* * *} \\
(0.776)\end{array}$ & $\begin{array}{c}0.550 \\
(1.553)\end{array}$ & 0.07 \\
\hline Government & $\begin{array}{l}1.232^{* * *} \\
(0.469)\end{array}$ & $\begin{array}{c}-0.044 \\
(0.346)\end{array}$ & $\begin{array}{c}1.002^{*} \\
(0.573)\end{array}$ & $0.32^{\mathrm{a}}$ & $\begin{array}{c}0.834 \\
(0.790)\end{array}$ & $\begin{array}{c}1.167 \\
(0.737)\end{array}$ & $\begin{array}{c}1.179 \\
(0.879)\end{array}$ & $0.31^{\mathrm{a}}$ \\
\hline Host Crisis & $\begin{array}{c}0.112 \\
(0.250)\end{array}$ & & & & $\begin{array}{c}8.459 \\
(6169)\end{array}$ & & & \\
\hline Home Crisis & & $\begin{array}{c}-0.111 \\
(0.344)\end{array}$ & & & & $\begin{array}{l}1.264^{* * *} \\
(0.413)\end{array}$ & & \\
\hline $\begin{array}{l}\text { Host*Home } \\
\text { Crisis }\end{array}$ & & & $\begin{array}{c}0.428 \\
(0.687)\end{array}$ & $0.11^{\mathrm{a}}$ & & & $\begin{array}{c}8.033 \\
(6920)\end{array}$ & $0.94^{\mathrm{a}}$ \\
\hline Constant & $\begin{array}{c}-1.166^{* * *} \\
(0.335) \\
\end{array}$ & $\begin{array}{c}-0.481 \\
(0.330) \\
\end{array}$ & $\begin{array}{l}-0.174 \\
(0.646)\end{array}$ & & $\begin{array}{c}-1.653^{* * *} \\
(0.341) \\
\end{array}$ & $\begin{array}{c}-2.109^{* * *} \\
(0.517) \\
\end{array}$ & $\begin{array}{c}-2.764^{* * *} \\
(0.980) \\
\end{array}$ & \\
\hline $\mathrm{N}$ & 342 & 302 & 189 & & 289 & 273 & 155 & \\
\hline Log likelihood & -122.15 & -130.24 & -74.04 & & -67.51 & -96.12 & -38.27 & \\
\hline Wald $\chi^{2}$ & 15.304 & 5.711 & 16.907 & & 9.376 & 24.292 & 9.627 & \\
\hline
\end{tabular}

${ }^{\mathrm{a}} \mathrm{dy} / \mathrm{dx}$ represents discrete change in the dummy variable from 0 to 1 .

Robust standard errors are shown in parentheses. *, **, and $* * *$ denote significance at the $10 \%, 5 \%$ and $1 \%$ levels, respectively. 


\section{CESifo Working Paper Series}

for full list see www.cesifo-group.org/wp

(address: Poschingerstr. 5, 81679 Munich, Germany, office@cesifo.de)

2941 Peter Debaere, Holger Görg and Horst Raff, Greasing the Wheels of International Commerce: How Services Facilitate Firms' International Sourcing, February 2010

2942 Emanuele Forlani, Competition in the Service Sector and the Performances of Manufacturing Firms: Does Liberalization Matter?, February 2010

2943 James M. Malcomson, Do Managers with Limited Liability Take More Risky Decisions? An Information Acquisition Model, February 2010

2944 Florian Englmaier and Steve Leider, Gift Exchange in the Lab - It is not (only) how much you give ..., February 2010

2945 Andrea Bassanini and Giorgio Brunello, Barriers to Entry, Deregulation and Workplace Training: A Theoretical Model with Evidence from Europe, February 2010

2946 Jan-Emmanuel De Neve, James H. Fowler and Bruno S. Frey, Genes, Economics, and Happiness, February 2010

2947 Camille Cornand and Frank Heinemann, Measuring Agents' Reaction to Private and Public Information in Games with Strategic Complementarities, February 2010

2948 Roel Beetsma and Massimo Giuliodori, Discretionary Fiscal Policy: Review and Estimates for the EU, February 2010

2949 Agnieszka Markiewicz, Monetary Policy, Model Uncertainty and Exchange Rate Volatility, February 2010

2950 Hans Dewachter and Leonardo Iania, An Extended Macro-Finance Model with Financial Factors, February 2010

2951 Helmuth Cremer, Philippe De Donder and Pierre Pestieau, Education and Social Mobility, February 2010

2952 Zuzana Brixiová and Balázs Égert, Modeling Institutions, Start-Ups and Productivity during Transition, February 2010

2953 Roland Strausz, The Political Economy of Regulatory Risk, February 2010

2954 Sanjay Jain, Sumon Majumdar and Sharun W. Mukand, Workers without Borders? Culture, Migration and the Political Limits to Globalization, February 2010

2955 Andreas Irmen, Steady-State Growth and the Elasticity of Substitution, February 2010

2956 Bengt-Arne Wickström, The Optimal Babel - An Economic Framework for the Analysis of Dynamic Language Rights, February 2010 
2957 Stefan Bauernschuster and Helmut Rainer, From Politics to the Family: How Sex-Role Attitudes Keep on Diverging in Reunified Germany, February 2010

2958 Patricia Funk and Christina Gathmann, How do Electoral Systems Affect Fiscal Policy? Evidence from State and Local Governments, 1890 to 2005, February 2010

2959 Betsey Stevenson, Beyond the Classroom: Using Title IX to Measure the Return to High School Sports, February 2010

2960 R. Quentin Grafton, Tom Kompas and Ngo Van Long, Biofuels Subsidies and the Green Paradox, February 2010

2961 Oliver Falck, Stephan Heblich, Alfred Lameli and Jens Suedekum, Dialects, Cultural Identity, and Economic Exchange, February 2010

2962 Bård Harstad, The Dynamics of Climate Agreements, February 2010

2963 Frederick van der Ploeg and Cees Withagen, Is There Really a Green Paradox?, February 2010

2964 Ingo Vogelsang, Incentive Regulation, Investments and Technological Change, February 2010

2965 Jan C. van Ours and Lenny Stoeldraijer, Age, Wage and Productivity, February 2010

2966 Michael Hoel, Climate Change and Carbon Tax Expectations, February 2010

2967 Tommaso Nannicini and Roberto Ricciuti, Autocratic Transitions and Growth, February 2010

2968 Sebastian Brauer and Frank Westermann, A Note on the Time Series Measure of Conservatism, February 2010

2969 Wolfram F. Richter, Efficient Education Policy - A Second-Order Elasticity Rule, February 2010

2970 Tomer Blumkin, Yoram Margalioth and Efraim Sadka, Taxing Children: The Redistributive Role of Child Benefits - Revisited, February 2010

2971 Chang Woon Nam and Georg Wamser, Application of Regionally Varying Additionality Degrees in the Practice of EU Cohesion Policy, February 2010

2972 Ali Bayar, Frédéric Dramais, Cristina Mohora, Masudi Opese and Bram Smeets, Modeling Russia for Climate Change Issues, February 2010

2973 Magnus Söderberg, Informal Benchmarks as a Source of Regulatory Threat in Unregulated Utility Sectors, March 2010

2974 Piotr Wdowiński and Marta Malecka, Asymmetry in Volatility: A Comparison of Developed and Transition Stock Markets, March 2010 
2975 Frans van Winden, Michal Krawczyk and Astrid Hopfensitz, Investment, Resolution of Risk, and the Role of Affect, March 2010

2976 Hyun-Ju Koh and Nadine Riedel, Do Governments Tax Agglomeration Rents?, March 2010

2977 Johann K. Brunner and Susanne Pech, Optimum Taxation of Bequests in a Model with Initial Wealth, March 2010

2978 Guglielmo Maria Caporale and Nicola Spagnolo, Stock Market Integration between three CEECs, Russia and the UK, March 2010

2979 Florian Englmaier, Ales Filipi and Ravi Singh, Incentives, Reputation and the Allocation of Authority, March 2010

2980 Konstantinos Angelopoulos, George Economides and Apostolis Philippopoulos, What is the Best Environmental Policy? Taxes, Permits and Rules under Economic and Environmental Uncertainty, March 2010

2981 Frederick van der Ploeg, Rapacious Resource Depletion, Excessive Investment and Insecure Property Rights, March 2010

2982 Wolfram F. Richter and Christoph Braun, Efficient Subsidization of Human Capital Accumulation with Overlapping Generations and Endogenous Growth, March 2010

2983 Francesco Cinnirella, Marc Piopiunik and Joachim Winter, Why Does Height Matter for Educational Attainment? Evidence from German Pre-Teen Children, March 2010

2984 Bernard Van Praag, Well-being Inequality and Reference Groups - An Agenda for New Research, March 2010

2985 Francesca Barion, Raffaele Miniaci, Paolo M. Panteghini and Maria Laura Parisi, Profit Shifting by Debt Financing in Europe, March 2010

2986 Alexander Haupt and Magdalena Stadejek, The Choice of Environmental Policy Instruments: Energy Efficiency and Redistribution, March 2010

2987 John Komlos and Marek Brabec, The Trend of BMI Values among US Adults, March 2010

2988 Emanuele Massetti and Lea Nicita, The Optimal Climate Policy Portfolio when Knowledge Spills across Sectors, March 2010

2989 Helmut Rainer and Thomas Siedler, Family Location and Caregiving Patterns from an International Perspective, March 2010

2990 Toru Kikuchi and Ngo Van Long, A Simple Model of Service Offshoring with Time Zone Differences, March 2010 
2991 Assaf Razin, Efraim Sadka and Benjarong Suwankiri, Migration and the Welfare State: Dynamic Political-Economy Theory, March 2010

2992 Bård Harstad, Buy Coal! Deposit Markets Prevent Carbon Leakage, March 2010

2993 Axel Dreher, Stephan Klasen, James Raymond Vreeland and Eric Werker, The Costs of Favoritism: Is Politically-driven Aid less Effective?, March 2010

2994 Sven Neelsen and Thomas Stratmann, Effects of Prenatal and Early Life Malnutrition: Evidence from the Greek Famine, March 2010

2995 Claude Hillinger and Bernd Süssmuth, The Quantity Theory of Money: An Assessment of its Real Linchpin Prediction, March 2010

2996 Matthew M. Chingos and Martin R. West, Do More Effective Teachers Earn More Outside of the Classroom?, March 2010

2997 Laurence Jacquet and Dirk Van de gaer, A Comparison of Optimal Tax Policies when Compensation or Responsibility Matter, March 2010

2998 Valentina Bosetti, Carlo Carraro, Romain Duval and Massimo Tavoni, What Should we Expect from Innovation? A Model-Based Assessment of the Environmental and Mitigation Cost Implications of Climate-Related R\&D, March 2010

2999 Scott Alan Carson, Nineteenth Century Stature and Family Size: Binding Constraint or Productive Labor Force?, March 2010

3000 Jukka Pirttilä and Ilpo Suoniemi, Public Provision, Commodity Demand and Hours of Work: An Empirical Analysis, March 2010

3001 Bertrand Candelon and Franz C. Palm, Banking and Debt Crises in Europe: The Dangerous Liaisons?, March 2010

3002 Joan Costa-i-Font and Marin Gemmill-Toyama, Does Cost Sharing really Reduce Inappropriate Prescriptions?, March 2010

3003 Scott Barrett, Climate Treaties and Backstop Technologies, March 2010

3004 Hans Jarle Kind, Tore Nilssen and Lars Sørgard, Price Coordination in Two-Sided Markets: Competition in the TV Industry, March 2010

3005 Jay Pil Choi and Heiko Gerlach, Global Cartels, Leniency Programs and International Antitrust Cooperation, March 2010

3006 Aneta Hryckiewicz and Oskar Kowalewski, Why do Foreign Banks Withdraw from other Countries? A Panel Data Analysis, March 2010 